\title{
THE IDEOLOGICAL PARADIGM OF PARLIAMENTARY PARTIES IN MODERN UKRAINE
}

\section{Shchedrova H. P.}

\section{INTRODUCTION}

Ideology is an integral part of any socio-political processes. The totality of different values and aspirations may correspond to both the "pure» type of ideologies and the synthesized form that has absorbed guidelines relevant to current historical era. A strong ideological message is able to consolidate society, make it monolithic. On the other hand, with the same level of effectiveness, the ideologically dominant one, as a rule, is not able to influence the political elite, although it is one of the criteria of the typology of the leading political class. Another value of ideology, which the domestic researcher O. Demina points to, is the ability to develop goals and ideals that allow individuals to identify themselves as a community, to establish a connection between people's worldviews and the rules of intersubjective normativity, as well as to determine the relationship between mentality and the behavior standards of society members ${ }^{1}$. Thus, the value of ideology as a system of conceptually formulated presentations, relevant ideas and views on political life is justified and probative, without losing priority in scientific researches.

The ideological component of political parties in political science, as a subject of analysis, has always occupied one of the leading places, in particular, in domestic political science. At the same time, the characteristics of the Ukrainian political parties often emphasized the absence of a stable ideology, since its basic features were often varied, supplemented and replaced by signs of different ideological political trends. However, this did not affect the intensity of the scientific search in Ukraine, which focused on the study of such aspects as the principles of political ideologies (N. Gedikova, F. Kyrylyuk, G. Kuts, M. Yakovlev), the role of ideology in society (V. Gorbatenko, O. Demina, O. Krasnokutsky, O. Makarenko), formation and development of ideological trends in Ukraine (V. Karlova, M. Mykhalchenko, O. Postol, O. Shulga), in particular, in the context of party building (A. Kolodiy, V. Kornienko, O. Matieshyn, M. Prymush, O. Sytnyk, G. Shypunov) and others.

The current stage of state formation in Ukraine was marked by the rich and unprecedented elections of the President of Ukraine and the People's Deputies of Ukraine in 2019. The electoral campaign again actualized such

1 Дьоміна О. Політична ідеологія як духовний регулятив суспільно-політичного розвитку. Грані. 2015. № 12/1 (128). С. 18-24. 
aspects of socio-political life as its ideological dimension and conceptual markers of political choice. Equally important are the commonalities and differences in program statements of parliamentary parties, especially among those with diametrically opposite positions. As a result, scientific research aims to determine the changes and directions of transformation of the ideological paradigm in the political field, on the example of parliamentary parties, which today are the authorized subjects of political and power decision-making. The research objectives are subordinate to these goals, the implementation of which will include the involvement of diverse methodological tools, interdisciplinary approaches and principles of scientific knowledge.

\section{The ideology of modern Ukrainian politics}

In the classical sense, ideology is identified with the core framework of political activity, which encompasses the functioning of all political institutions, institutional relations, personified dimensions of politics and so on and so forth. In the conditions of subordination to the policy of the social sphere of life, it can be argued that the political ideology exerts a permanent pressure on social transformations. The definition of the essence of ideology is formed at the intersection of political science, philosophy, cultural studies, other sciences and even religion. The concept of «ideology» dates back to the 18th century, when in France the attitude towards the idea as an integral part of being began to form. It should be noted that both ideology and its propagandists - ideologists - were in those days perceived in the negative sense as opponents of the current government of Napoleon. A certain categorization of the term was initiated by the French philosopher D. de Tracy. His authorship is the interpretation of ideology as a science of human thinking and social ideas, which must find explanations in the worldview and phenomena of consciousness through the principles of ethics, morality, politics ${ }^{2}$. According to one version, the thinker was looking for a meaningful correspondence to the process of analyzing phenomena and ideas, while rejecting metaphysics and psychology. Instead, he settled on an ideology that, according to D. de Tracy, should have resolved the contradictions in society without interfering with the social structure ${ }^{3}$. One of the modern definitions of ideology was suggested by American professor D. Kettler, who emphasized that it is a set of beliefs and concepts through which occurs the perception and comprehension of the world ${ }^{4}$.

2 Траси А. Д. де. Идеология в собственном смысле слова. М.: Академический Проект. 2013. 332 с.

${ }^{3}$ Лютий Т. Ідеологія: матриця ілюзій, дискурсів і влади. URL: http://ekmair.ukma.edu.ua/bitstream/handle/123456789/12444/3.\%20Liutyi_Ideolohiia_ matrytsia_iliuzii_dyskursiv_i_vlady.pdf?sequence=1\&isAllowed=y. C. 105.

${ }^{4}$ Кеттлер Д. Ідеологія. Енциклопедія політичної думки. К.: Дух і літера. 2000. C. $141-142$. 
However, in the context of the study, we refer to the concept of political ideology, which in the context of Ukrainian realities is appropriate to be perceived through the prism of a functional approach. It is about understanding the ideology as a tool that changes the human mind, changes the world. Its special purpose is to provide a person with the ability to see the past, present and future of the world through a system of interconnected ideas, as well as to bring these principles into human activity, and thus align the world order with these ideas. We can assume that the ideology of domestic politics is more likely not a set of ascertaining values prevailing in society, but a predictive model of order and aspirations that embody the goals of social development.

Drawing on many years of research by the Institute of Sociology of the NAS of Ukraine, A. Shulga analyzes the problem of ideological trends and changes in preferences about them among the population of Ukraine. It is noted that in the early $90 \mathrm{~s}$, almost $60 \%$ of respondents could not say which ideology was closer to them: they had not decided yet, had not understood, or none of the ideological currents had attracted them at all. More than 20 years have passed - and this figure has hardly changed: $55 \%$ of respondents do not choose any of the ideologies as close to themselves ${ }^{5}$. Such trends indicate, in our view, that in the absence of a real ideological choice, society was also unable to formulate a relevant request. As a rule, attention and interest in certain ideas was intensified artificially, using political technologies and manipulations. For example, the state often used the issue of Ukrainian nationalism, the unity of the Slavic nations, the fight against the Soviet past and so on. Some accents have always accompanied the main ideological principle of domestic politics «for all the good, against all the bad», but for «good» and «bad» in each ideology are fixed different values and ideals.

Domestic researcher S. Datsyuk, formulating the vision of Ukrainian ideology, claims that she must choose - whether be weak and marginal or strong and total. The author implies that both a consistent nationalist ideology and a meaningless democratic one eventually turn into total ideologies. At the same time, «Ukrainian politics uses an ideological centaur - a nationaldemocratic ideology with its two conflicting approaches. Two total ideologies cannot be applied in one culture. Only one of them has to survive - either authoritarian nationalism or democratic globalism» ${ }^{6}$. Thus, the thesis is argued that at the present stage of development the new Ukrainian ideology will be

${ }^{5}$ Шульга О. Націоналісти чи ліберали: які політичні течії набирають популярності в Україні. Аналітичний портал «Слово $i$ діло». 22 серпня 2017 p. URL: https://www.slovoidilo.ua/2017/08/22/kolonka/aleksandr-shulha/polityka/naczionalisty-chyliberaly-yaki-politychni-techiyi-nabyrayut-populyarnosti-ukrayini.

${ }_{6}^{6}$ Дацюк С. Погляд на можливість нової ідеології Часопис «Ï». 2012. URL: http://www.ji-magazine.lviv.ua/dyskusija/2012/Dacyuk_Pohlyad_na_mozhlyvist_nov_ ideolog.htm. 
extremely fragmentary, having absorbed the features of the national and democratic, but getting rid of traits of the total.

Emphasizing that ideology in Ukraine should serve the purpose of setting, it turns out that political ideology, or ideology of politics, should develop and establish a set of goals to which would be subject to the political institutions. The events in Ukraine over the past six years that twice led to a change in the political elite showed a common desire of citizens to uphold democratic values protection of individual rights and freedoms, support of private property, fair competition and market relations, fight against corruption, increased transparency of public policy, guarantees of freedom of foreign policy choice and so on and so forth. A kind of wrapper for such a set of goals could be the ideology of liberalism, the essence of which is the protection and support of the common good through the protection of the individual.

The liberal mechanism, described in due time by the English thinker J. Locke, provides for the conclusion of a social contract between the population and the authorities. It looks as if the new Liberal government is taking responsibility for the realization of socially important aspirations. In case of of non-fulfillment of its obligations, the government may be changed peacefully or removed by revolutionary means. At first glance, a simple mechanism in Ukraine has a number of nuances in practice. Firstly, in the conditions of the formation of a liberal ideology, governments may not be liberal, provoking a dissonance between existing corruption and the values of liberalism. Secondly, the postulates of liberalism completely legalize the events of the Revolution of Dignity 2013-2014, when the people exercised their right to remove power that did not fulfill the terms of the social contract.

It is appropriate to draw a parallel with the eastern neighbor, the Russian Federation, where the values of liberalism in the current conditions are perceived as a hostile ideology of the current authorities. That is why the format of the Russian opposition is characterized as «liberal», and its actions are gradually taken outside the conventional legal field. This is a sort of a manifestation of half-liberalism when the people were only entitled to elect a ruler, but did not have the authority to control, criticize and change him. Concerning the functional dimension of ideology, we note that there is a distortion of the content of ideology, which essentially subordinates socially important ideas to the actual state order. In Ukraine, however, the liberal mechanism does not work, say, in the part of the civic political consciousness due to low levels of participation in elections, interest in studying political programs, personified assessment of political forces, etc.

Returning to the statement about the fragmentation of the ideology of Ukrainian politics, let us dwell on manifestations of conservatism. It was reflected mainly in the functioning of the political elite and the ideology of its self-perception, which, despite the change of personalities, still prefers 
established methods and principles of activity. Conservative, or rather stably closed, remain internal institutional and institutional relationships, also associated with an unsettled system of checks and balances. Reforming the system of public administration in the conditions of preservation the previous powers, preferences and in the absence of modernization of institutional competencies is a national feature of domestic conservatism. This is one of the reasons why the process of circulation of political elites in our country is not full and complete. At the same time, politicians in Ukraine cannot acquire classical features of conservative ideology due to a number of objective reasons: firstly, there are practically no carriers of this doctrine in the state, and secondly, within the framework of independent state, Ukraine has no acquired values or principles that can be «conserve».

According to the liberal component of the ideology of politics in Ukraine, it is worth adding about those features that give the right to call our liberalism formal. These include the existence of a number of political parties which, in their own name, have laid membership in the values of liberalism (the Liberal Party of Ukraine, the Liberal Democratic Party of Ukraine, the Christian Liberal Party of Ukraine, the Political Party «Liberal Ukraine», etc.), and the constitutional consolidation of major liberal values (protection of human rights and freedoms and decent living conditions, guaranteeing freedom of thought and speech, inviolability of private property, protection of competition in business activities, etc.). These features are mainly declarative and do not affect the implementation of public policy. Yes, none of the listed parties get to the parliament on their own.

Another criterion for measuring liberality is the maturity level of civil society. The German Liberal Policy Fund, «the Friedrich Naumann Foundation for Freedom», proposes this definition: «a liberal state is a civil society in which the state does not oppose the citizen as a powerful government but in which the citizen is a state» ${ }^{7}$. From this point of view, it is important to recall the expert study of the Civil Society Stability Index in Ukraine, which in 2018 has fallen by 0.1 points compared to 2017. Experts point out that the decline was due to a significant deterioration in two blocks: the legal environment and advocacy ${ }^{8}$. Specifying the causes of this situation, were mentioned the attacks on activists and campaigns to discredit their activities, efforts to introduce additional reporting for all public organizations with burdensome procedures, etc. The NGO advocacy index, that is, the ability to influence processes, has fallen by 0.1 points, as a number of reforms initiated by the non-governmental sector have not been implemented. There is

${ }^{7}$ Фонд Фрідріха Науманна за Свободу. URL: https://ukrajina.fnst.org.

${ }^{8}$ Індекс стабільності громадянського суспільства в Україні у 2018 році погіршився на 0,1 пункта - звіт. Украӥнський кризовий медіа-центр. 2019. URL: http://uacrisis.org/ua/ 73649-civil-society-index-2018. 
also still a significant difference between the achievements of public organizations in big cities and at the local level.

Improvements include the simplification of the procedure for state financing of public organizations.

At the same time, there is a public perception of civil society, whose measurements in 2019 showed that involvement in civic activities in Ukraine remains low, but awareness of activism and interest in it has a positive dynamic. $40.5 \%$ of respondents assess the level of civil society development as average, while $34 \%$ of respondents give a negative assessment and $12 \%$ give a high rating. The level of non-involvement of citizens in public organizations is noticeable - the indicator of $7-8 \%$ has not changed in the last six years, but answers about the reasons have been changed - from the lack of time in 2013 to the lack of interest in $2019^{9}$. Therefore, the state of development of civil society remains diverse and unstable, it still depends on state intervention, which can be considered systematic adoption of normative documents that are intended to influence the process of institutionalization of civil society (for example, National Strategy for Promoting Civil Society Development).

According to non-classical political ideologies, in Ukraine one can watch only situational and rather controlled manifestations of nationalism that does not find mass support among the population. In the context of adaptation to the Ukrainian realities of postmodern ideologies, in particular environmentalism and feminism, relevant non-governmental organizations play their active role, which directly or indirectly interacting with political institutions, but do not play a significant role in the functioning of the political system. However, we add that, for example, the principle of equal opportunities for men and women is enshrined in the Statute and in the program of the "European Solidarity» political party, which is a kind of precedent for Ukraine.

The aim of consolidating Ukrainian society is also linked to a certain unifying ideology, defining it as nationwide and not identifying it with a particular political institute. Social democracy, social liberalism, liberal nationalism, pan-Europeanism, center-right politics, Christian democracy - the spectrum of value orientations in domestic politics has no common vector. On the one hand, such a vector may contradict the established principle of political and ideological pluralism, on the other - it is entirely consistent with the interests of building a viable nation state. According to the Ukrainian researcher V. Karlova, the widely publicized and actively implemented idea of «deideologization» and «depoliticization» after the collapse of the USSR led to negative consequences - «ideological vacuum» and destabilization of social development, a significant weakening of the foundations of the new

${ }^{9}$ Громадянське суспільство в Україні: погляд громадян. Фонд «Демократичні ініціативи імені I. Кучеріва». URL : https://dif.org.ua/article/gromadyanske-suspilstvo-vukraini-poglyad-gromadyan. 
statehood $^{10}$. In this regard, well-known researcher M. Golovatyi rightly noted that unprincipled, non-ideological societies do not exist in nature now, because any activity of people and nations is driven precisely by ideas, the system of values in which society grows and on which it is based ${ }^{11}$.

Although the Constitution of Ukraine enshrined the principle of political, economic and ideological pluralism, this document can also be considered as a certain list of rules and values of a particular nationwide ideology. The reasons that it has not yet been able to fully realize its function of consolidation of society are due to the lack of proper political and legal culture and respect for the Basic Law, problems of balance of power, the elite's rejection of the rule of law principle - first of all, the need for the application and interpretation the norms of the right to be guided by the interests of the individual and society, not by an official, party or state. Based on the principle of universal subordination of the Constitution to all political decisions and political and social norms, this document, which has been praised in the countries of developed democracy, could become a kind of ideological manifesto of Ukrainian national ideology.

The main carriers of ideologies in Ukraine, as in other states, are whether there should be political parties, which by definition form the ideological spectrum of the political sphere in the country. A number of studies in their conclusions substantiate the thesis that there are no ideological parties in Ukraine.

\section{Program goals of domestic parliamentary parties: a comparative analysis}

The study of the ideological foundations of party programs is updated in Ukraine during each electoral campaign. The use of different approaches and techniques every time finds new arguments in favor of the absence of parties with certain ideological orientation in the state. Moreover, ideology that is often declared by party leaders does not correspond to the party's program goals or contradict the name of the party and so on. Elections to the Verkhovna Rada of Ukraine in the summer of 2019 caused a new stage in increasing attention to the ideological analysis of the programs of political parties. According to the result of the will of the citizens, having overcome the five percent barrier, five political forces entered the parliament - a political party «Servant of the People» (43.16\%), a political party «Opposition Platform - For Life» (13.05\%), a political party All-Ukrainian Union «Batkivshchyna»

10 Карлова В. Проблеми формування загальнонаціональної ідеології в Україні. Вісник Національної академії державного управління. 2013. № 11. URL: http://visnyk.academy.gov.ua/wp-content/uploads/2013/11/2010-4-4.pdf.

${ }^{11}$ Головатий М. Ідейні засади розбудови Української України: стан та проблеми. Персонал. 2007. № 1. С. 14. 
(Fatherland) (8.18\%), a political party «European Solidarity» (8.1\%), a political party «Voice» $(5.82 \%)^{12}$. Among the current parliamentary parties, two are new political forces («Servant of the People», «Voice»), two continued their activities by changing their names («Opposition Platform - For Life», «European Solidarity»), one already breaking the electoral barrier to the Rada (All-Ukrainian Union «Batkivshchyna»). We emphasize the aspects embedded in the programs of these parties, finding out the common and distinct features in the ideologies of political opponents.

The analysis of the relevant documents submitted by the party organizations to the Central Election Commission during the election campaign showed the prevalence of common ideas and aspirations of the current parliamentary parties. We emphasize that these common features mainly reflect the values of liberal ideology, namely, various freedoms, respect and protection of human rights, support for the development of civil society and youth, development and implementation of innovations, reduction and optimization of taxes, protection of private property and entrepreneurship, development of markets through politics demonopolization, encouraging community initiative in the context of continuing the decentralization reform. The principle of protection freedom of speech, which recently has become especially relevant, has even been brought to some points in party programs: the impossibility of controlling the media («Voice»), to deprive media owners of the opportunity to influence the journalists’ activities («Servant of the People»).

Each party formulated its dominant markers: the defense sector and Euro-Atlantic integration in «European Solidarity», peace and personnel reloading of power in "Servant of the People», consolidation of the population, the return of neutrality and multi-vector policies in «Opposition Platform - For Life», a new economic course of a country in All-Ukrainian Union «Batkivshchyna» (Fatherland) and justice through overcoming corruption and monopolies in «Voice» ${ }^{1314151617}$. Issues of war and peace and the vector of foreign policy became the fundamental aspects that touched upon all program documents. Thus, the formula of peace through victory is supported by the parties «European Solidarity» and «Voice», peace through




involvement and expansion of international institutions appears in «Batkivshchyna» (Fatherland) program, peace through dialogue and compromises in «Opposition Platform - For Life». «Servant of the People» party relied on President V. Zelensky in this, promising in the program «to provide legislative support to Presidential initiatives aimed at restoring the territorial integrity and state sovereignty of Ukraine» ${ }^{18}$.

Certainly, foreign policy was determined through the prism of choice between West and East. Support for Ukraine's accession to the European Union and NATO is enshrined in the programs of three political forces «European Solidarity», «Batkivshchyna» (Fatherland) and «Voice». «Servant of the People» assumes the responsibility to fulfill the Association Agreement with the European Union, as well as to expand cooperation with the EU and NATO, but does not fix the purpose of joining these organizations. «Opposition Platform - For Life» supports the opposite opinion, which supports political multi-vectorism, active neutrality, revision of conditions for Ukraine's participation in the World Trade Organization and the Free Trade Area with the EU, and the restoration of trade and economic ties with the Russian Federation and CIS countries ${ }^{19}$.

In our opinion, the program of the political party «Opposition Platform - For Life» is the most controversial in terms of the promoted principles. On the one hand, the party is in favor of a comprehensive policy of reconciliation and consent in order to consolidate the population, insisting on the introduction of a "moratorium on topics that split the country». On the other hand, the document contains theses on the autonomy of the Donbas, amnesty for the participants in the war in the east of the country, restoration of ties with Russia, providing training in Russian and languages of national minorities, etc. These items do not quite fit the criterion of consolidation and are quite ambiguously perceived by different parts of the Ukrainian population. At the same time, the party identified its program as a «fair social contract between the party and the Ukrainian people», which is the classic tenet of liberalism. The mechanism of liability for non-compliance with the contingent clauses of such an agreement has not yet been regulated by domestic legislation.

The issue of land sale, which is on the agenda in the state, was reflected only in the programs of two parties: All-Ukrainian Union «Batkivshchyna» (Fatherland) strongly opposed the sale of agricultural land, and «Opposition Platform - For Life» left the right to make a final decision through an allUkrainian referendum. By the way, «Servant of the People» also suggested

${ }^{18}$ Центральна виборча комісія. URL: https://www.cvk.gov.ua/pls/vnd2019/ wp502pt001f01=919pf7171=403.html.

${ }^{19}$ Центральна виборча комісія. URL: https://www.cvk.gov.ua/pls/vnd2019/ wp502pt001 f01=919pf7171=393.html. 
the initiative of actively introducing such form of communication with the population as referendums.

By visualizing the texts of party programs using the Tag Cloud service, you can capture also word markers that characterize certain party priorities in one way or another. For "Servant of the People», it is mainly the verb «we will introduce», "we will create», "we will carry out», "we will deprive», "we will transfer»; for «Opposition Platform - For Life» - «policy», «Donbass», «security», «priority steps», for «Batkivshchyna» (Fatherland) - «we», «new», «insurance», «account» and a number of other economic terms, for «European Solidarity» - «citizens», «EU», «promote», «development», «life», and for «Voice» - «we», «people», «state», «victory» (Fig. 1). In the context of usage of this service, the word «Ukraine» was found common in four political forces (except All-Ukrainian Union «Batkivshchyna» (Fatherland)). Of course, this approach cannot be considered scientifically valid, so we do not analyze the visual part, but only state it as a fact.

One of the reasons that each program can be called declarative is the principles of further parliamentary activity. There were almost no points of contact in the inter-factional interaction of the victorious political parties in the Verkhovna Rada of Ukraine of the IXth convocation, despite calls for unity and consolidation, the common vision of the fundamental principles of state formation in the context of protecting the rights and freedoms of citizens, minimizing bureaucratic pressure, building a healthy society. The situation is balanced by the unprecedented formation of a mono-majority of deputies of the political party «Servant of the People» (252 deputies) (Fig. 1).

The statutes of political parties also formulate certain ideological principles, but rarely specify them. In particular, a clearly defined ideological affiliation is not enshrined in the Statute of «European Solidarity», which is still on the official site of the Petro Poroshenko Block «Solidarity». The document states that party secretariats provide the ideology of the party, but but there is no fixed ideological dominance, only the protection of «universal human values» and participation in the development of a «sovereign, legal, democratic, socially oriented and economically developed state» are mentioned ${ }^{20}$.

The Statute of the All-Ukrainian Union «Batkivshchyna» (Fatherland) has been formulated in the same way. However, the charter document states that «being an associate member of the European People's Party as an alliance of centrist and Christian-democratic parties on the continent, it fully and completely shares the worldviews stated in the main EPP program documents» ${ }^{21}$. Theses on protection of «universal human values» and «achievement and

${ }^{20}$ Статут політичної партії «Блок Петра Порошенка «Солідарність». URL: https://solydarnist.org/wp-content/uploads/2016/12/statut_solidarnist.pdf.

${ }^{21}$ Статут Всеукраїнське об'єднання «Батьківщина». URL: https://ba.org.ua/ wp-content/uploads/2017/12/statut14-6.pdf. 
constant improvement of social justice and high standard of living, full membership of Ukraine in the European Union, alignment with European standards of social sphere, economy and political system» are also present.

The values professed by the «Opposition Platform - For Life» are enshrined in the section of the Statute of the Party Task, in particular, are about «ensuring the perception of a person as the highest social value», "promoting the formation of a civil consciousness among the population of Ukraine, based on the national interests of the state and universal human values», etc ${ }^{22}$. Characterizing the ideology of the party from the outside, experts point to its tendencyto socialism, social democracy and social liberalism, and more critical towards Russophile social liberalism.

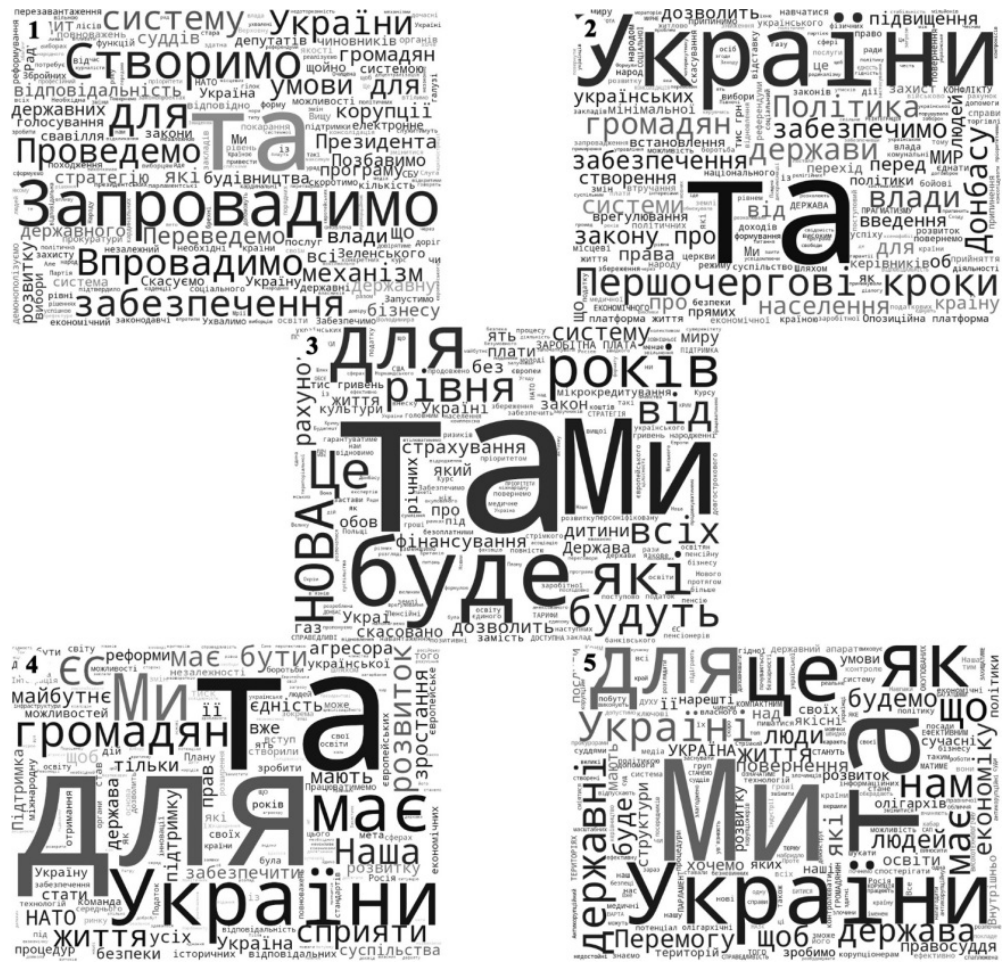

Fig. 1. Political party programs in tag cloud format (1 - Servant of the People, 2. - Opposition Platform - For Life, 3 - Batkivshchyna (Fatherland), European Solidarity, 5 - Voice)

${ }^{22}$ Статут політичної партії «Опозиційна Платформа - За Життя». URL: http://zagittya.com.ua/ua/page/ustav.html. 
The newly created political parties «Servant of the People» and «Voice» did not make their charters public.

In the absence of stable ideological norms, Ukrainian political parties are still often characterized as «interest clubs» or «political projects», emphasizing certain manifestations of leadership. In our view, the last statement is based on the predominance of the party's personalized perception over its ideological superstructure. In general, this is still one of the leading features of domestic politics. According to researcher S. Grabovsky, this situation is caused by the fact that Ukraine is late with the establishment of political parties on the European model. In the late 1980s in Ukraine, as well as in its western neighbors, a number of political parties emerged with a clear ideology and program of action. But unlike the countries of Central and Eastern Europe and the Baltic States, where parliamentary elections were held immediately after the fall of communism on party lists, there were no such elections in Ukraine until 1998. By that time, merging of parties and business had already occurred, which did not contribute to the continued existence of ideological parties ${ }^{23}$.

Another reason for the de-ideologization of political parties in Ukraine is the response to society's request. We mean that citizens are waiting for a leader, not an ideology. This is evidenced by data from sociological surveys over the last three years. Thus, in 2017, almost half of the respondents said that there are no political leaders in Ukraine who could effectively run the country $^{24}$. In 2018, 62\% of citizens believed that Ukraine needed new political leaders (in 2013, 49\% of respondents said this). It was emphasized that such leaders should emerge from new political forces (33.5\%), existing nonprimary political parties (30\%), civil society organizations (28\%) and humanitarian or technical intellectuals $(26 \%)^{25}$. In 2019, $67 \%$ of the respondents said that Ukraine needs a leader who is able to unite, reconcile and calm society; $24 \%$ - for a leader inclined to dictatorship and rigid ordering $^{26}$. It is significant that according to the analytical platform VoxUkraine, in the summer of 2019 most Ukrainians were inclined to believe that the state should have a strong influence on both the economy and personal

${ }^{23}$ Грабовський С. Ідеологічні партії в Україні зникли, бо ж на партійну діяльність завжди потрібні гроші. Радіо Свобода. 22 червня 2017 p. URL: https://www.radiosvoboda.org/ a/28572938.html.

${ }^{24} 45,5 \%$ українців не бачать гідного політичного лідера - опитування. Украӥнська правда. 14 грудня 2017 p. URL: https://www.pravda.com.ua/news/2017/12/14/7165529.

${ }^{25}$ Дві третини українців хочуть бачити нових політичних лідерів. Дзеркало тижня. Дві третини українців хочуть бачити нових політичних лідерів. 1 серпня 2018 р. URL: https://dt.ua/UKRAINE/dvi-tretini-ukrayinciv-hochut-bachiti-novih-politichnih-lideriv284545_html.

${ }^{26}$ Моніторинг електоральних настроїв українців: січень 2019. Сочіологічна група «Рейтинг». URL: http://ratinggroup.ua/research/ukraine/monitoring_elektoralnyh_nastroeniy_ ukraincev_yanvar_2019.html. 
freedoms. Previous studies have shown that most members of influential political forces were also inclined to believe $\mathrm{so}^{27}$. This is a significant coincidence of the positions of Ukrainian citizens and party leaders on the political compass, where liberal values lose their positions.

In general, Ukraine systematically demonstrates a tendency towards left-wing or left-centrist ideologies in times of economic decline and political crises. As a consequence of the Soviet past, these trends are subconsciously associated with citizens with state guarantees of well-being, even if their level is minimal and such that it does not correspond to a sufficient level of needs.

Along with the classical types of ideology, domestic practice forms its own ideological spectrum - the ideology of peace associated with military operations in the Donbass, the European ideology based on European values and formed under the influence of the process of European integration, and the ideology of populism, which is determined by the opposition of political slogans and the activation of party activity during of the electoral process.populism and political ideology. All these facts indicate that the ideologization of political space in Ukraine is transforming in the direction of acquiring responses to the challenges and needs of a particular historical period, borrowing values from outside by engaging in global politics and gravitating towards a certain international community.

\section{CONCLUSIONS}

The concept of «political ideology» has come a long way in evolution, and in the modern dimension is interpreted as a steady set of values, guidelines and aspirations that correspond to the current state of political life. Political ideology in Ukraine is rather a prognostic model of the order that society expects.

The ideological superstructure of national state formation is characterized by a combination of national (due to the political past) and democratic (corresponding to modern challenges and trends) aspects. On the way to the perception of liberal values, Ukraine faces difficulties in implementing the mechanism of concluding the so-called «social agreement». The unstable system of checks and balances, the lack of effective channels of communication between citizens and the political elite, the high level of distrust in government bodies and the disappointment in the activities of political institutions have led to several large-scale crises of confidence in the authorities. Correct the situation should the systematic formation of a national idea and a consolidating state ideology, the conductors of which would be political parties.

${ }^{27}$ Що думають українці про державний контроль економіки та особистих свобод? VoxUkraine. 5 червня 2019 p. URL: https://voxukraine.org/uk/sprava-nalivo-shho-dumayutbilshist-ukrayintsiv-pro-derzhavnij-kontrol-ekonomiki-ta-osobistih-svobod. 
Political parties of Ukraine mention the ideology and values quite often, but they almost never specify these concepts, using, for example, categories such as «universal human values», «European values» or «principles of democracy». These terms are rather vague and always have their own specifics due to the peculiarities of the political regime, the level of institutionalization of the state-making apparatus, the state of political culture and the political elite. Liberal values, which are universal in accordance with the requirements and needs of the time, have become the most popular in the declarative part of the activities of parties. They are reflected in both party programs and statutes, but in the real work of parliamentary parties they are often combined with the values of socialism and conservatism. Ideological principles are often replaced by political technologies, such as the manipulation of slogans that are often changed.

The characterization of party ideologies as declarative or decorative is not a negative feature of parties as such, but rather indicates a certain deideologization of political parties in Ukraine, the level of their maturity as a political institute. Among the factors and features of party functioning in domestic partogenesis, we note the establishment of stable party structures and their territorial organizations, with respect to transparent financial reporting. Aspects of ideological design and, in particular, ideologies of internal party relations remain fragmentary and deformed. We assume that this is a consequence of both the lack of personal experience in building political parties and the destructive consequences of mono-party system and monoideology in the last few decades before Ukraine gained independence.

\section{SUMMARY}

The question of ideology has always been an important topic of public debate, but the ideological component of socio-political life is on the state's default agenda - without the development and progress of holistic paradigm. The vision of ideology, both at the level of the state and its individual institutions, as well as at the civic level, are rather blurred and fragmented liberal ideas with an admixture of center-right elements and left-wing values. On the one hand, this is a sign of the embodied pluralism of thoughts, on the other - the result of a scattering needs, aspirations and guidelines in the conditions of the state's inability to produce a constant set of consolidating ideas.

Political parties as leaders of ideological trends in Ukraine are characterized as deideologized, but not devoid of the markers of certain ideologies - social democracy, social liberalism, pan-Europeanism, rightcentrism, etc. In the conditions of the declarations of political slogans, we note the rise of populist ideology, which intensifies its manifestations in the electoral period. The reasons for such tendencies can be considered the lack of historical experience of building ideological parties, the rate on personification 
of the party, not the formation of its ideological superstructure, the lack of demand for ideology from a society, which, first of all, requires a political leader with a certain set of managerial and individual qualities.

The level of maturity of ideology in society, the state, and political parties is a measure of the level of maturity of socio-political relations. Awareness of common goals and priorities will be the key to further developing a nationwide system of political values.

\section{REFERENCES}

1. 45,5\% українців не бачать гідного політичного лідера - опитування. Українська правда. 14 грудня 2017 p. URL: https://www.pravda. com.ua/news/2017/12/14/7165529.

2. Головатий М. Ідейні засади розбудови Української України: стан та проблеми. Персонал. 2007. № 1. С. 12-18.

3. Грабовський С. Ідеологічні партії в Україні зникли, бо ж на партійну діяльність завжди потрібні гроші. Paдіо Свобода. 22 червня 2017 p. URL: https://www.radiosvoboda.org/a/28572938.html.

4. Громадянське суспільство в Україні: погляд громадян. Фонд «Демократичні ініціативи імені I. Кучеріва». URL : https://dif.org.ua/article/ gromadyanske-suspilstvo-v-ukraini-poglyad-gromadyan.

5. Дацюк С. Погляд на можливість нової ідеології. Часопис «ї». 2012. URL: http://www.ji-magazine.lviv.ua/dyskusija/2012/Dacyuk_ Pohlyad_na_mozhlyvist_nov_ideolog.htm.

6. Дві третини українців хочуть бачити нових політичних лідерів. Дзеркало тижня. 1 серпня 2018 p. URL: https://dt.ua/UKRAINE/dvi-tretiniukrayinciv-hochut-bachiti-novih-politichnih-lideriv-284545_html.

7. Дьоміна О. Політична ідеологія як духовний регулятив суспільно-політичного розвитку. Грані. 2015. № 12/1 (128). С. 18-24.

8. Індекс стабільності громадянського суспільства в Україні у 2018 році погіршився на 0,1 пункта - звіт. Украӥнський кризовий медіацентр. 2019. URL: http://uacrisis.org/ua/73649-civil-society-index-2018.

9. Карлова В. Проблеми формування загальнонаціональної ідеології в Україні. Вісник Наиіональної академії державного управління. 2013. № 11. URL: http://visnyk.academy.gov.ua/wp-content/uploads/2013/ 11/2010-4-4.pdf.

10. Кеттлер Д. Ідеологія. Енциклопедія політичної думки. К.: Дух і літера. 2000. $472 \mathrm{c.}$

11. Лютий T. Ідеологія: матриця ілюзій, дискурсів і влади. URL: http://ekmair.ukma.edu.ua/bitstream/handle/123456789/12444/3.\%20Liutyi_Ide olohiia_matrytsia_iliuzii_dyskursiv_i_vlady.pdf?sequence=1\&isAllowed=y. 
12. Моніторинг електоральних настроїв українців: січень 2019. Соиіологічна група «Рейтинг». URL: http://ratinggroup.ua/research/ukraine/ monitoring_elektoralnyh_nastroeniy_ukraincev_yanvar_2019.html.

13. Статут Всеукраїнське об’єднання «Батьківщина». URL: https://ba.org.ua/wp-content/uploads/2017/12/statut14-6.pdf.

14. Статут політичної партії «Блок Петра Порошенка «Солідарність». URL: https://solydarnist.org/wp-content/uploads/2016/12/statut_ solidarnist.pdf.

15. Статут політичної партії «Опозиційна Платформа - За Життя». URL: http://zagittya.com.ua/ua/page/ustav.html.

16. Траси А. Д. де. Идеология в собственном смысле слова. М.: Академический Проект. 2013. 332 с.

17. Фонд Фрідріха Науманна за Свободу. URL: https://ukrajina.fnst.org.

18. Центральна виборча комісія. URL: https://www.cvk.gov.ua.

19. Шульга О. Націоналісти чи ліберали: які політичні течії набирають популярності в Україні. Аналітичний портал «Слово $i$ діло». 22 серпня 2017 p. URL: https://www.slovoidilo.ua/2017/08/22/kolonka/ aleksandr-shulha/polityka/naczionalisty-chy-liberaly-yaki-politychni-techiyinabyrayut-populyarnosti-ukrayini.

20. Що думають українці про державний контроль економіки та особистих свобод? VoxUkraine. 5 червня 2019 p. URL: https://voxukraine.org/ uk/sprava-nalivo-shho-dumayut-bilshist-ukrayintsiv-pro-derzhavnij-kontrolekonomiki-ta-osobistih-svobod.

Information about the author: Shchedrova H. P., Doctor of Political Sciences, Professor, Head of the Department of Political Science and International Relations, Higher educational institution "Alfred Nobel University» 18, Sicheslavska Naberezhna str, Dnipro, 49000, Ukraine 